\title{
Nuclear Emergency Management using Accident Consequence Analysis Code
}

\author{
Borhan Uddin, Gazi Muhammad*, and Kim, Juyoul**
}

\begin{abstract}
Shin Kori Unit 3 is a new pressurized water reactor in Advanced Power Reactor 1400, which was developed by Korea Hydro and Nuclear Power Co. and commenced commercial operation in December 2016. We calculated the radionuclide concentrations and related radiation doses at the early stage of accidents under the assumption of hypothetical severe nuclear accidents in Shin Kori Unit 3. In this study, the radiological source terms of the accident scenarios were evaluated using the radiological assessment system for consequence analysis code, which has been used as a regulatory software tool for emergency response applications developed by the United States Nuclear Regulatory Commission. In general, the atmospheric transport, dispersion, and deposition processes of radioactive materials can be simulated by the Gaussian model using a straight-line trajectory Gaussian plume model for short distances and a Lagrangian Gaussian puff model for long distances. The most dangerous scenarios were observed during winter when we considered two accident scenarios, namely, long-term station blackout (LTSBO) and loss-of-coolant accident (LOCA), based on the reactor conditions and seasonal effects. The total effective dose equivalent values for LTSBO and LOCA were estimated to be 14 and $0.08 \mathrm{mSv}$, respectively, in the precautionary action zone of $5 \mathrm{~km}$ in two days after the accident. According to Korean regulations on urgent public protective actions, the criteria are $10 \mathrm{mSv}$ in two days for indoor sheltering and $50 \mathrm{mSv}$ in one week for public evacuation. In the LTSBO case, we found that immediate public protective measures were required. Appropriate decisions must be made by the off-site emergency management center under the Nuclear Safety and Security Commission in Korea.
\end{abstract}

Key words : Nuclear Emergency, Consequence Analysis, LTSBO, LOCA

\section{요 지}

신고리 3호기는 한국수력원자력(주에서 개발한 신형 가압경수로(APR1400)로서 2016년 12월부터 상업운전을 개시하였다. 신고리 3호기에 가상의 중대사고를 가정하여 사고 초기 시간에 따른 방사성 핵종 농도와 방사선량 변화를 계산하였다. 본 연구에서는 미국 원자력규제위원회에서 개발한 방사능방재 비상대응 규제검증 전산코드인 RASCAL을 사용하여 사고 시나리오 의 방사선원항을 평가하였다. 일반적으로 방사성 물질의 대기 중 수송, 확산 및 침적 과정은 가우시안 플륨모델로 모사되는데 근거리에는 직선궤적 가우시안 플륨모델, 원거리에는 라그랑지안 가우시안 퍼프모델을 사용하였다. 장기정전사고와 냉각재상실 사고 시나리오에 대해 원자로 상태와 계절변화를 고려하여 소외 방사선량을 평가한 결과 가장 위험한 시나리오는 겨울에 발생하였고 사고 후 2 일에 예방적보호조치구역인 $5 \mathrm{~km}$ 에서 총유효선량당량의 최대값은 장기정전사고의 경우 $14 \mathrm{mSv}$, 냉각재상 실사고의 경우 $0.08 \mathrm{mSv}$ 로 평가되었다. 긴급주민보호조치에 관한 국내 규제기준은 옥내대피의 경우 이틀간 $10 \mathrm{mSv}$, 주민소개의 경우 일주일간 $50 \mathrm{mSv}$ 이다. 장기정전사고시 즉각적인 주민보호조치가 필요하며 이 경우 원자력안전위원회 산하 현장방사능지휘 센터에서 적절한 의사결정을 내려야 한다.

핵심용어 : 원자력비상, 결말분석, 장기정전사고, 냉각재상실사고

\footnotetext{
*Member, M.S. Candidate, Department of NPP Engineering, KEPCO International Nuclear Graduate School (E-mail: borhan_baec@yahoo.com) **Corresponding Author, Member, Assistant Professor, Department of NPP Engineering, KEPCO International Nuclear Graduate School (Tel: +82-52-712-7306, Fax: +82-52-712-7375, E-mail: jykim@kings.ac.kr)
} 


\section{Introduction}

Since the Three Mile Island accident in 1979, Chernobyl accident in 1986 and Fukushima accident in 2011, a great emphasis has been put on assessing emergency response capabilities for different types of stakeholders including electric utilities, regulatory bodies and local communities. Estimation of radioactive materials released to the atmosphere, which is usually termed as source term estimation, constitutes an important part of nuclear emergency response. This source term can provide a necessary input for the consecutive simulation of atmospheric dispersion and radiological dose assessment to the public. Based on the dose assessment, corresponding emergency response actions could be recommended such as whether people should be guided by evacuation or shelterinplace protective actions (Zhao et al., 2015). Radiological source term estimation, atmospheric dispersion analysis and radiation dose assessment have been considered as the most important safety concerns in the area of emergency response after a nuclear accident. Therefore, public concerns after nuclear accidents emphasized an absolute necessity to identify and address potential health effects which were closely related with the accurate dose assessment to the public around nuclear power plants (NPPs) (Ahangari et al., 2017).

The siting of NPP is one of important parameters from the point of view of emergency preparedness and response. There are two kinds of site, i.e., on the site (on-site) and off the site (off-site). The on-site area is the area under the control of operators or first responders, and the off-site area is the area beyond that area. In addition, for the off-site, there are two kinds of emergency planning zone (EPZ), precautionary action zone (PAZ) and the urgent protective action planning zone (UPZ). Protective actions within PAZ are to be taken before or shortly after a release of radioactive materials on the basis of conditions at NPPs, and protective actions within UPZ are to be mainly taken on the basis of environmental monitoring. The EPZ is divided into PAZ and UPZ which have a radius of $5 \mathrm{~km}$ and a radius of $20 \sim 30 \mathrm{~km}$ from the nuclear facility, respectively (Lee et al., 2016).

Radiation exposure following the release of radioactive materials in nuclear accident can occur through various pathways of exposure. Total effective dose equivalent (TEDE) can be generally calculated from three pathways including external cloud shine, external ground shine and internal inhalation which contributes committed dose equivalent (CDE). In this study, we estimated off-site radiological doses for severe nuclear accidents of Shin Kori unit 3 which is named an advanced power reactor 1400 (APR1400), a twoloop pressurized water reactor (PWR) with rated thermal output of 4,000 MWt or electrical power of 1,400 MWe. It is located at the latitude of $35.3236^{\circ}$ and the longitude of $129.2915^{\circ}$ in the administrative district of Ulsan city. The elevation of the site is $9.5 \mathrm{~m}$ from the sea level. The geological location and reactor design parameters of Shin Kori unit 3 are shown in Fig. 1 and Table 1, respectively, according to design control documents of APR1400 (KEPCO and KHNP, 2014). The residential population around Shin Kori unit 3 and the relevant meteorological data are shown in Tables 2 and 3, respectively (KMA, 2019). Using the information above, the effectiveness of emergency management for Shin Kori unit 3 was addressed in terms of radiological source term, TEDE and thyroid CDE by a regulatory accident consequence analysis code. Multiple simulations were performed for two accidents of long-term station blackout (LTSBO) and loss of coolant accident (LOCA) considering the atmospheric conditions in the time of morning and evening of four seasons. Through the preliminary analysis, the evening time of winter was found to have the most significant effect on the accident (Uddin, 2019). The worst scenario in the evening time of winter was chosen and analyzed for two hypothetical accidents of LTSBO and LOCA in this study.

\section{Materials and Methods}

Radiological assessment system for consequence analysis (RASCAL) is the software developed by United States Nuclear Regulatory Commission (NRC) emergency operations center to estimate projected doses from radiological emergencies (U.S. NRC, 2017a). The code can provide the rapid dose assessment for an incident or accident and help any decisionmaking process such as whether the public should be considered shelterinplace or immediate evacuation. RASCAL can compute nuclear reactor's source terms, airborne transport of activities through both Gaussian plume and puff models, and the resulting offsite doses (Athey et al., 2015).

Atmospheric dispersion is generally governed by a differential equation called the diffusion equation. With a set of assumptions that can be reasonably applied to the atmospheric processes, this diffusion equation has a specific and closed-form algebraic solution of Gaussian function. In a Cartesian coordinate system with $\mathrm{x}$ and $\mathrm{y}$ axes in the horizontal plane and $\mathrm{z}$ in the vertical, the normalized concentration in the vicinity is as follows. 


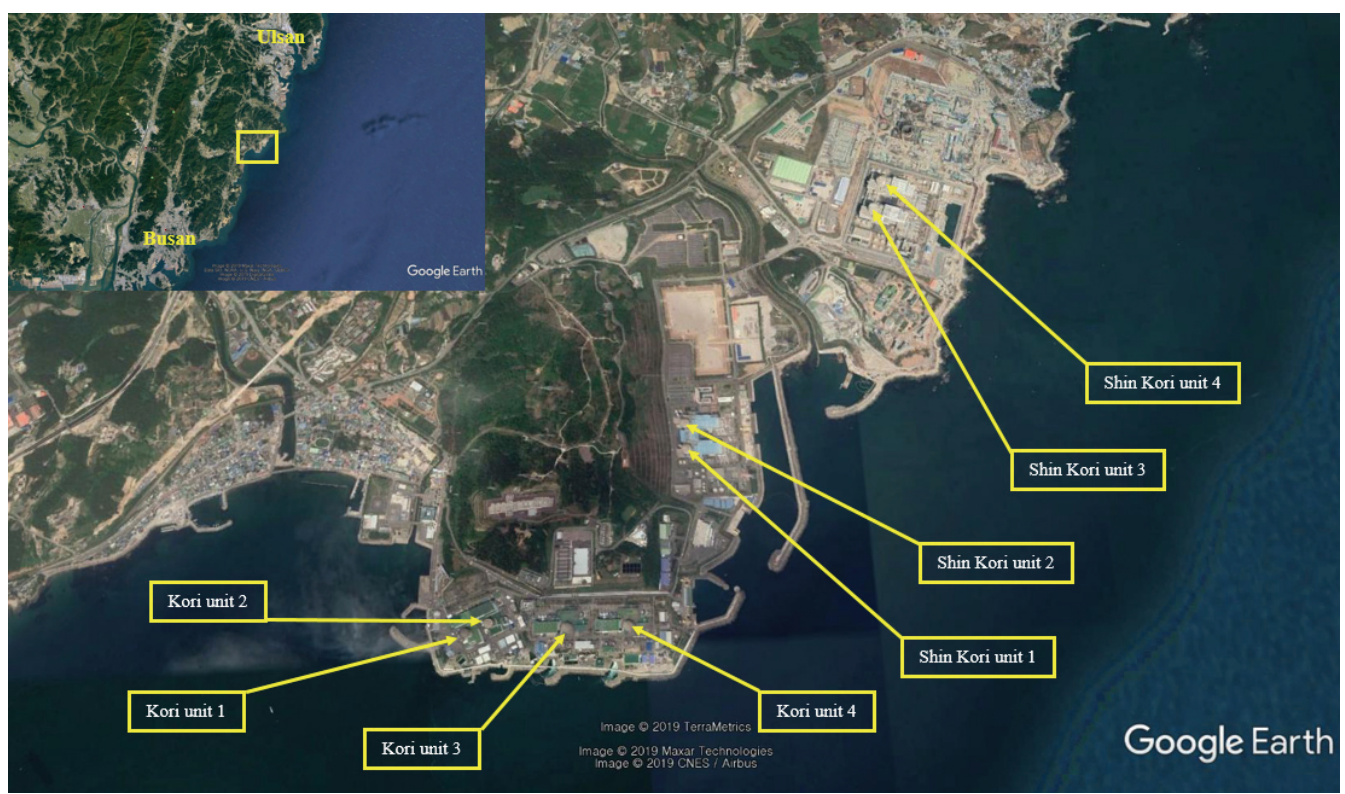

Fig. 1. Geographic Information Around Shin Kori Unit 3

Table 1. Location and Parameters of Shin Kori Unit 3

\begin{tabular}{|c|c|}
\hline \multicolumn{2}{|c|}{ Location } \\
\hline City & Seosaeng-myeon, Ulju-gun, Ulsan \\
\hline $\begin{array}{c}\text { Latitude/Longitude/Sea level } \\
\text { UTC offset }\end{array}$ & $\begin{array}{c}35.3236{ }^{\circ} \mathrm{N}, 129.2915{ }^{\circ} \mathrm{E}, 9.5 \mathrm{~m} \\
9 \mathrm{hrs}\end{array}$ \\
\hline \multicolumn{2}{|c|}{ Reactor parameters } \\
\hline Reactor power & 3,983 MWt \\
\hline Average burnup & 28,914 MWd/MTU \\
\hline Containment type & PWR dry ambient \\
\hline Containment volume & $3.13 \times 10^{6} \mathrm{ft}^{3}$ \\
\hline Design pressure & $50 \mathrm{lb} / \mathrm{in}^{2}$ \\
\hline Design leak rate & $0.10 \% / \mathrm{d}$ \\
\hline Coolant mass & $2.92 \times 10^{5} \mathrm{~kg}$ \\
\hline Assemblies in core & 241 \\
\hline Type of steam generator & U-Tube \\
\hline Water mass of steam generator & $218,000 \mathrm{~kg}$ \\
\hline \multicolumn{2}{|c|}{ Release pathway } \\
\hline $\begin{array}{l}\text { Type } \\
\text { Release height }\end{array}$ & $\begin{array}{l}\text { PWR dry containment leakage or failure } \\
\qquad 60 \mathrm{~m}\end{array}$ \\
\hline
\end{tabular}

Table 2. Residential Population Around Shin Kori Unit 3

\begin{tabular}{c|c}
\hline Distance $(\mathrm{km})$ & Population \\
\hline $0 \sim 2$ & 2,367 \\
$2 \sim 4$ & 6,338 \\
$4 \sim 6$ & 5,068 \\
$6 \sim 8$ & 15,185 \\
\hline $8 \sim 10$ & 22,308 \\
$10 \sim 20$ & 551,853 \\
$20 \sim 35$ & $3,464,351$ \\
\hline Total & $4,067,470$ \\
\hline
\end{tabular}


Table 3. Meteorological Information in this Study

\begin{tabular}{|c|c|c|c|c|c|c|}
\hline Season & Time & Type & $\begin{array}{c}\text { Direction } \\
\text { (degree) }\end{array}$ & $\begin{array}{c}\text { Speed } \\
(\mathrm{m} / \mathrm{s})\end{array}$ & $\begin{array}{c}\text { Stability } \\
\text { Class }\end{array}$ & $\begin{array}{l}\text { Temp } \\
\left({ }^{\circ} \mathrm{C}\right)\end{array}$ \\
\hline \multirow{33}{*}{ Winter } & 2017/12/12;09:00 & Obs & 320 & 3.8 & B & -5.8 \\
\hline & $2017 / 12 / 12 ; 10: 00$ & Obs & 290 & 4.4 & B & -4.6 \\
\hline & $2017 / 12 / 12 ; 11: 00$ & Obs & 290 & 4.4 & B & -3.4 \\
\hline & $2017 / 12 / 12 ; 12: 00$ & Obs & 290 & 4.1 & B & -2.1 \\
\hline & $2017 / 12 / 12 ; 13: 00$ & Obs & 320 & 5.0 & $\mathrm{C}$ & -1.8 \\
\hline & $2017 / 12 / 12 ; 14: 00$ & Obs & 320 & 5.0 & $\mathrm{C}$ & -1.5 \\
\hline & $2017 / 12 / 12 ; 15: 00$ & Obs & 320 & 4.5 & B & -0.9 \\
\hline & $2017 / 12 / 12 ; 16: 00$ & Obs & 290 & 4.1 & B & -1.1 \\
\hline & $2017 / 12 / 12 ; 17: 00$ & Obs & 270 & 3.8 & B & -1.9 \\
\hline & $2017 / 12 / 12 ; 18: 00$ & Obs & 290 & 2.8 & $\mathrm{~B}$ & -2.5 \\
\hline & $2017 / 12 / 12 ; 19: 00$ & Obs & 360 & 1.5 & A & -3.3 \\
\hline & $2017 / 12 / 12 ; 20: 00$ & Obs & 320 & 2.6 & B & -3.5 \\
\hline & $2017 / 12 / 12 ; 21: 00$ & Obs & 320 & 2.4 & B & -3.8 \\
\hline & $2017 / 12 / 12 ; 22: 00$ & Obs & 320 & 1.7 & A & -4.1 \\
\hline & $2017 / 12 / 12 ; 23: 00$ & Obs & 340 & 2.1 & $\mathrm{~B}$ & -4.4 \\
\hline & $2017 / 12 / 13 ; 00: 00$ & Obs & 320 & 2.2 & B & -4.9 \\
\hline & $2017 / 12 / 13 ; 01: 00$ & Obs & 340 & 2.6 & $\mathrm{~B}$ & -4.8 \\
\hline & $2017 / 12 / 13 ; 02: 00$ & Obs & 320 & 1.6 & A & -5.6 \\
\hline & $2017 / 12 / 13 ; 03: 00$ & Obs & 360 & 3.0 & B & -5.5 \\
\hline & $2017 / 12 / 13 ; 04: 00$ & Obs & 360 & 2.9 & B & -4.4 \\
\hline & $2017 / 12 / 13 ; 05: 00$ & Obs & 290 & 6.9 & $\mathrm{C}$ & -4.1 \\
\hline & $2017 / 12 / 13 ; 06: 00$ & Obs & 290 & 6.2 & $\mathrm{C}$ & -4.8 \\
\hline & $2017 / 12 / 13 ; 07: 00$ & Obs & 340 & 3.1 & B & -5.2 \\
\hline & $2017 / 12 / 13 ; 08: 00$ & Obs & 70 & 2.2 & $\mathrm{~B}$ & -5.6 \\
\hline & 2017/12/13; 09:00 & Obs & 90 & 2.5 & B & -3.9 \\
\hline & $2017 / 12 / 13 ; 10: 00$ & Obs & 320 & 4.3 & B & -2.5 \\
\hline & $2017 / 12 / 13 ; 11: 00$ & Obs & 320 & 4.4 & B & -1.0 \\
\hline & $2017 / 12 / 13 ; 12: 00$ & Obs & 290 & 5.0 & $\mathrm{C}$ & 0.4 \\
\hline & $2017 / 12 / 13 ; 13: 00$ & Obs & 290 & 5.7 & $\mathrm{C}$ & 1.6 \\
\hline & $2017 / 12 / 13 ; 14: 00$ & Obs & 290 & 4.6 & $\mathrm{~B}$ & 2.5 \\
\hline & $2017 / 12 / 13 ; 15: 00$ & Obs & 340 & 3.4 & $\mathrm{~B}$ & 2.5 \\
\hline & $2017 / 12 / 13 ; 16: 00$ & Obs & 360 & 3.2 & $\mathrm{~B}$ & 1.9 \\
\hline & $2017 / 12 / 13 ; 17: 00$ & Obs & 340 & 2.0 & A & 0.5 \\
\hline
\end{tabular}

$$
\begin{aligned}
& \frac{\chi(x, y, z)}{Q}=\frac{1}{(2 \pi)^{3 / 2} \sigma_{x} \sigma_{y} \sigma_{z}} \times \exp \left[-\frac{1}{2}\left(\frac{x-x_{o}}{\sigma_{x}}\right)^{2}\right] \\
& \times \exp \left[-\frac{1}{2}\left(\frac{y-y_{o}}{\sigma_{y}}\right)^{2}\right] \times \exp \left[-\frac{1}{2}\left(\frac{z-z_{o}}{\sigma_{z}}\right)^{2}\right]
\end{aligned}
$$

where $X$ is the concentration $\left(\mathrm{Ci} / \mathrm{m}^{3}\right.$ or $\left.\mathrm{g} / \mathrm{m}^{3}\right)$ and $\mathrm{Q}$ is the amount of material released $(\mathrm{Ci}$ or $\mathrm{g})$. $\sigma$ is the dispersion parameter $(\mathrm{m})$ which is a function of distance from the release point. When combined with a transport mechanism to move the center of the puff $\left(x_{0}, y_{0}, z_{0}\right)$, Eq. (1) is a simplified version of the puff model in RASCAL (Ahangari et al., 2017).

The basic scenario of LTSBO was assumed to have been initiated by an external event which caused the loss of offsite and onsite AC power at Shin Kori unit 3. It was assumed that the reactor was shut down at 5:30, 12 December 2017. Reactor cooling was maintained for a period of several hours but was ultimately lost, at which point the coolant boiled away. Core damage and releases from the core began after core uncovery. Emergency diesel generators (EDGs) were providing the electric power and emergency core cooling systems (ECCS) were available and operating for 5 hrs. These 
inputs were combined with the shutdown time to determine when the reactor coolant would begin to boil off. Then, RASCAL added a fixed boil-off duration of $8 \mathrm{hrs}$ according to NUREG-1935 to determine the time of core melt and release (U.S. NRC, 2012). EDGs became inoperable after $5 \mathrm{hrs}$ and the core began to heat to the point of meltdown. The containment sprays then became inoperable which increased containment pressure and leakage to a release rate of 5\% per day. Power was restored at 21:00 and the core was recovered. Containment pressure was reduced by 04:30 of the next day and then containment leakage was stopped (U.S. NRC, 2017b).

In case of LOCA, it was also assumed that there was a major rupture in the primary coolant system after the extreme natural disaster. As a result, the reactor was tripped at 18:00, 12 December 2017. Due to significant loss of coolant passed into the containment building, the core was uncovered at 19:00. Release from the containment to the atmosphere was assumed to follow the leak rate of design control documents of APR1400 (KEPCO and KHNP, 2014). Release rate was assumed to be 3\% per day. At 01:00 of the next day, operators were able to recover the core. Containment remained at high pressure which kept the release ongoing and pressure was not reduced until 05:00 of the next day. At that time, the release rate was set to be $0.1 \%$ per day (U.S. NRC, 2017c).

\section{Results and Discussion}

The accident scenario and radiological source terms for LTSBO were shown in Table 4. Noble gases, iodine and particulate nuclides were remarkably released to the atmosphere. Among the released activities to the atmosphere, the proportional portion of noble gases was higher by $51.4 \%$ and that of iodine was $27.7 \%$. This was because the reactor core was melted in the case of LTSBO. It was observed that activities were increasing until the time of 21:00 as shown in Figs. 2 and 3. After that, the activities of ${ }^{135} \mathrm{Xe},{ }^{132} \mathrm{I}$ and ${ }^{132} \mathrm{Te}$ were decreasing slowly because of their relatively short half-lives which were $9.1 \mathrm{hrs}$, $2.3 \mathrm{hrs}$ and 3.2 days, respectively. But, ${ }^{133} \mathrm{Xe}$ remained steady after reaching the maximum point compared to others. ${ }^{133} \mathrm{I}$ and ${ }^{131}$ I were showing the similar characteristics and they decreased rapidly with half-lives of $20.8 \mathrm{hrs}$ and 8 days, respectively. ${ }^{135} \mathrm{I}$ had a half-life less than $7 \mathrm{hrs}$ and it shortly decayed to ${ }^{135} \mathrm{Xe}$. It was also observed that the radioactive plume was moving towards the south-east direction from Shin Kori unit 3 and accumulated TEDEs during $48 \mathrm{hrs}$ since 18:30 of 12 December were shown in Fig. 4. TEDE and thyroid CDE for LTSBO were shown in Tables 5 and 6 , respectively. TEDE and thyroid CDE were $14 \mathrm{mSv}$ and $160 \mathrm{mSv}$, respectively, at about $5 \mathrm{~km}$ of PAZ in the evening time of winter season. Calculated values of TEDE and thyroid CDE in PAZ were higher than the Korean regulations on the indoor sheltering of $10 \mathrm{mSv}$ in 2 days and thyroid protection level of $100 \mathrm{mSv}$, and therefore it was found that indoor sheltering and distribution of iodine prophylaxis should be immediately implemented for short-term protective measures. In this situation, an immediate evacuation should be decided by the off-site emergency management center (OEMC) which was responsible for emergency decision-making process under the nuclear safety and security commission (NSSC) in Korea.

Table 4. Scenario and Source Term for LTSBO

\begin{tabular}{|c|c|c|}
\hline \multicolumn{3}{|c|}{ Accident scenario } \\
\hline Type & \multicolumn{2}{|c|}{ Long Term Station Black Out } \\
\hline Shutdown & \multicolumn{2}{|c|}{$2017 / 12 / 12 ; 05: 30$} \\
\hline Release from core starts & \multicolumn{2}{|c|}{$2017 / 12 / 12 ; 18: 30$} \\
\hline Core recovered & \multicolumn{2}{|c|}{$2017 / 12 / 12 ; 21: 00$} \\
\hline \multicolumn{3}{|c|}{ Release events } \\
\hline $2017 / 12 / 12 ; 18: 30$ & \multirow{2}{*}{\multicolumn{2}{|c|}{$\begin{array}{c}\text { Leak rate }(\% \text { vol) } 5.0 \% / \mathrm{d} \\
\text { Sprays off }\end{array}$}} \\
\hline $2017 / 12 / 12 ; 18: 30$ & & \\
\hline $2017 / 12 / 13 ; 04: 30$ & \multicolumn{2}{|c|}{ Leak rate $(\%$ vol) $0.1 \% / \mathrm{d}$} \\
\hline \multicolumn{3}{|c|}{ Activities released to the atmosphere } \\
\hline & $\mathrm{Bq}$ & $\%$ of total \\
\hline Noble gas & $1.5 \times 10^{17}$ & 51.4 \\
\hline Iodine & $8.1 \times 10^{16}$ & 27.7 \\
\hline Particulate & $6.1 \times 10^{16}$ & 20.9 \\
\hline Total & $2.92 \times 10^{17}$ & 100.0 \\
\hline
\end{tabular}




\section{Time-Dependent Source Term}

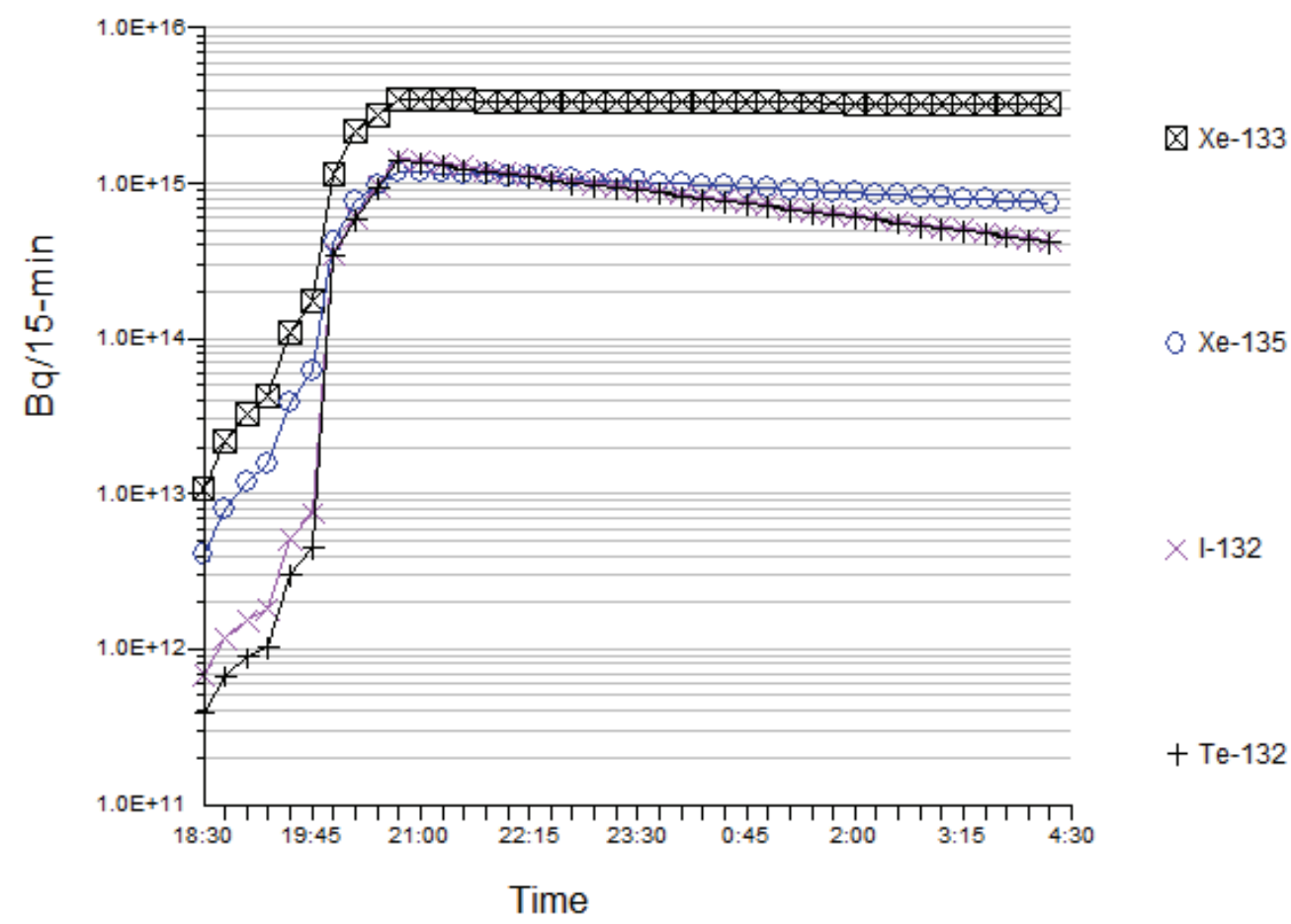

Fig. 2. Source Terms of ${ }^{133} \mathrm{Xe},{ }^{135} \mathrm{Xe},{ }^{132} \mathrm{I}$ and ${ }^{132} \mathrm{Te}$ for LTSBO

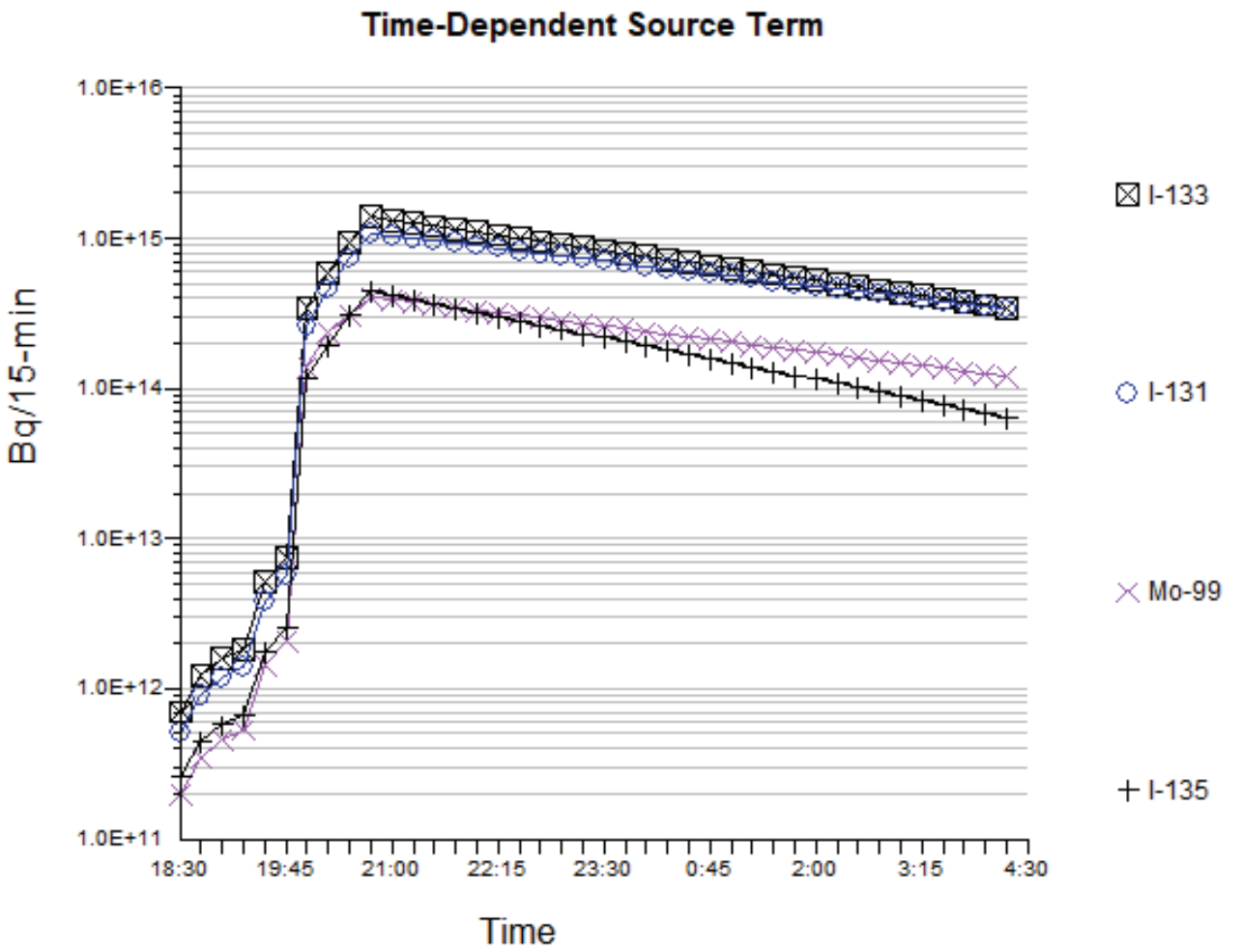

Fig. 3. Source Terms of ${ }^{133} \mathrm{I},{ }^{131} \mathrm{I},{ }^{99} \mathrm{Mo}$ and ${ }^{135} \mathrm{I}$ for LTSBO 


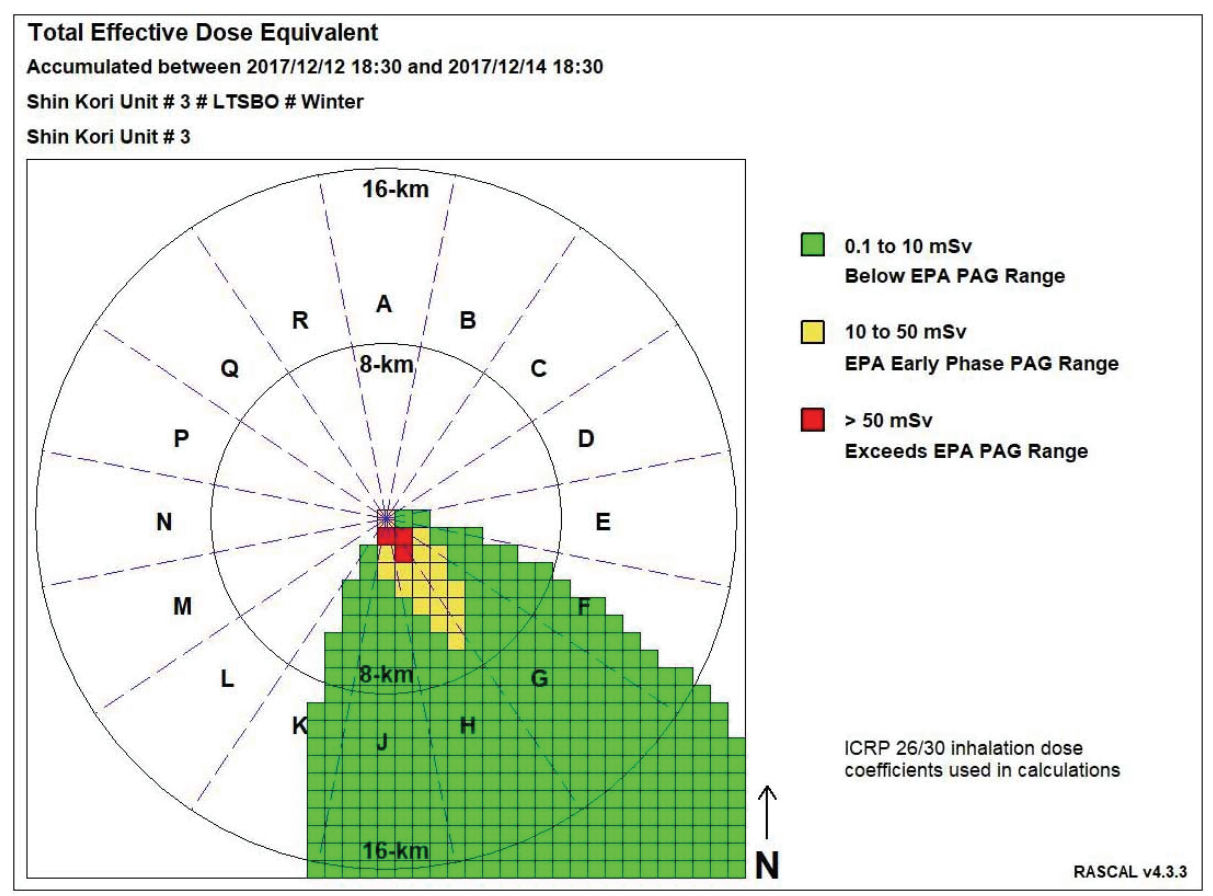

Fig. 4. Contour Plot of TEDE for LTSBO

Table 5. TEDE for LTSBO and LOCA in Winter

\begin{tabular}{c|c|c|c|c}
\hline \multirow{2}{*}{$\begin{array}{c}\text { Distance from release } \\
(\mathrm{km})\end{array}$} & \multicolumn{2}{|c}{ TEDE (mSv) } \\
\cline { 2 - 5 } & Morning & Evening & Morning & \multicolumn{2}{c}{ LOCA } \\
\cline { 2 - 5 } & 16 & 28 & 0.093 & 0.170 \\
4.22 & 7.4 & 14 & 0.043 & 0.080 \\
6.44 & 4.8 & 9.3 & 0.031 & 0.057 \\
\hline 8.05 & 3.8 & 7.4 & 0.030 & 0.053 \\
11.3 & 2.8 & 6.4 & 0.031 & 0.060 \\
\hline 16.1 & 2.0 & 5.2 & 0.024 & 0.019 \\
\hline \\
\cline { 2 - 5 } & 1.4 & 3.9 & 0.017 & 0.031 \\
\end{tabular}

Table 6. Thyroid CDE for LTSBO and LOCA in Winter

\begin{tabular}{c|c|c|c|c}
\hline \multirow{2}{*}{$\begin{array}{c}\text { Distance from release } \\
(\mathrm{km})\end{array}$} & \multicolumn{4}{|c}{ Thyroid CDE (mSv) } \\
\cline { 2 - 5 } & Morning & Evening & Morning & \multicolumn{2}{c}{ LOCA } \\
\cline { 2 - 5 } & 170 & 330 & 0.61 & 0.92 \\
4.22 & 79 & 160 & 0.28 & 0.46 \\
6.44 & 51 & 110 & 0.18 & 0.24 \\
\hline 8.05 & 39 & 86 & 0.14 & 0.26 \\
11.3 & 31 & 80 & 0.12 & 0.21 \\
\hline 16.1 & 23 & 66 & 0.09 & 0.16 \\
\hline 24.1 & 16 & 49 & 0.08 & 0.13 \\
\hline
\end{tabular}


The accident scenario of LOCA and top eight radionuclides released to the atmosphere for both accidents of LTSBO and LOCA were shown in Tables 7 and 8, respectively. Among the released activities to the atmosphere, the proportional portion of noble gases was higher by $99 \%$ but that of iodine was smaller by $0.3 \%$ unlike LTSBO. This was because reactor core was not melted in case of LOCA. It was observed that released activities were increasing very fast to their maximum values within $2 \mathrm{hrs}$ and then, the activities were decreasing slowly until 05:00 of the next day as shown in Figs. 5 and $6 .{ }^{133} \mathrm{Xe}$ and ${ }^{135} \mathrm{Xe}$ were showing almost similar characteristics and decreased slowly with 5.2 days and $9.2 \mathrm{hrs}$ of half-lives, respectively. The behaviors of ${ }^{88} \mathrm{Kr}$ and ${ }^{85 \mathrm{~m}} \mathrm{Kr}$ were different because both particles' half-lives were relatively short, i.e., $2.8 \mathrm{hrs}$ and $4.5 \mathrm{hrs}$, respectively. ${ }^{87} \mathrm{Kr}$ decreased very quickly with a short half-life of 76.3 minutes and there was little contribution to the population to radiation exposure during the early phase of a nuclear accident. ${ }^{135 \mathrm{~m}} \mathrm{Xe}$ also decreased very fast to an unstable isotope of xenon with a half-life of $9.2 \mathrm{hrs}$. As shown in Fig. 7, the radioactive plume whose TEDE was above $10 \mathrm{mSv}$ did not reach to the distance of $8 \mathrm{~km}(5$ miles) from the facility. TEDE and thyroid CDE were 0.08 $\mathrm{mSv}$ and $0.46 \mathrm{mSv}$, respectively, at about $5 \mathrm{~km}$ of PAZ in the evening time of winter season. Both values were sufficiently low when compared with the criteria of $10 \mathrm{mSv}$ for 2 days because most radioactive isotopes released to the atmosphere belonged to noble gases. The accident scenario of LTSBO proved to be more dangerous than that of LOCA in this study, As shown in Figs. 8 and 9, this result could be convinced by the fact that estimated TEDEs of Shin Kori unit 3 for LTSBO and LOCA showed similar trends with those of Arkansas unit 2 and Braidwood unit 1 in the United States, whose reactor powers were 3,026

Table 7. Scenario and Source Term for LOCA

\begin{tabular}{|c|c|c|}
\hline \multicolumn{3}{|c|}{ Accident scenario } \\
\hline Type & \multicolumn{2}{|c|}{ Loss of Coolant Accident } \\
\hline Shutdown & \multicolumn{2}{|c|}{$2017 / 12 / 12 ; 18: 00$} \\
\hline Release from core starts & \multicolumn{2}{|c|}{$2017 / 12 / 12 ; 19: 00$} \\
\hline Core recovered & \multicolumn{2}{|c|}{$2017 / 12 / 13 ; 01: 00$} \\
\hline \multicolumn{3}{|c|}{ Release events } \\
\hline $2017 / 12 / 12 ; 19: 00$ & \multirow{2}{*}{\multicolumn{2}{|c|}{$\begin{array}{c}\text { Leak rate }(\% \text { vol) } 3.0 \% / \mathrm{d} \\
\text { Sprays on }\end{array}$}} \\
\hline $2017 / 12 / 12 ; 19: 00$ & & \\
\hline 2017/12/13; 05:00 & \multicolumn{2}{|c|}{ Leak rate $(\%$ vol) $0.1 \% / d$} \\
\hline \multicolumn{3}{|c|}{ Activities released to the atmosphere } \\
\hline & $\mathrm{Bq}$ & $\%$ of total \\
\hline Noble gas & $1.287 \times 10^{17}$ & 99.0 \\
\hline Iodine & $3.4 \times 10^{14}$ & 0.3 \\
\hline Particulate & $9.2 \times 10^{14}$ & 0.7 \\
\hline Total & $1.3 \times 10^{17}$ & 100.0 \\
\hline
\end{tabular}

Table 8. Top eight Source Terms for LTSBO and LOCA

\begin{tabular}{c|c|c|c|c}
\hline \multirow{2}{*}{} & \multicolumn{2}{|c|}{ LTSBO } & \multicolumn{2}{c}{ LOCA } \\
\cline { 2 - 5 } & Nuclide & $\mathrm{Bq}$ & Nuclide & $8.7 \times 10^{16}$ \\
\hline 2 & ${ }^{133} \mathrm{Xe}$ & $1.1 \times 10^{17}$ & ${ }^{133} \mathrm{Xe}$ & $2.7 \times 10^{16}$ \\
3 & ${ }^{135} \mathrm{Xe}$ & $3.2 \times 10^{16}$ & ${ }^{135} \mathrm{Xe}$ & $7.2 \times 10^{15}$ \\
\hline 4 & ${ }^{132} \mathrm{I}$ & $2.8 \times 10^{16}$ & ${ }^{88} \mathrm{Kr}$ & $4.1 \times 10^{15}$ \\
5 & ${ }^{132} \mathrm{Te}$ & $2.7 \times 10^{16}$ & ${ }^{85 \mathrm{Kr}}$ & $3.4 \times 10^{14}$ \\
6 & ${ }^{133} \mathrm{I}$ & $2.5 \times 10^{16} \mathrm{Kr}$ & $2.6 \times 10^{15}$ \\
\hline 7 & ${ }^{131} \mathrm{I}$ & $2.1 \times 10^{16}$ & ${ }^{133 \mathrm{~m}} \mathrm{Xe}$ & $2.5 \times 10^{15}$ \\
8 & ${ }^{99} \mathrm{Mo}$ & $8.0 \times 10^{15}$ & ${ }^{135 \mathrm{~m}} \mathrm{Xe}$ & $1.5 \times 10^{15}$ \\
\hline
\end{tabular}


Time-Dependent Source Term

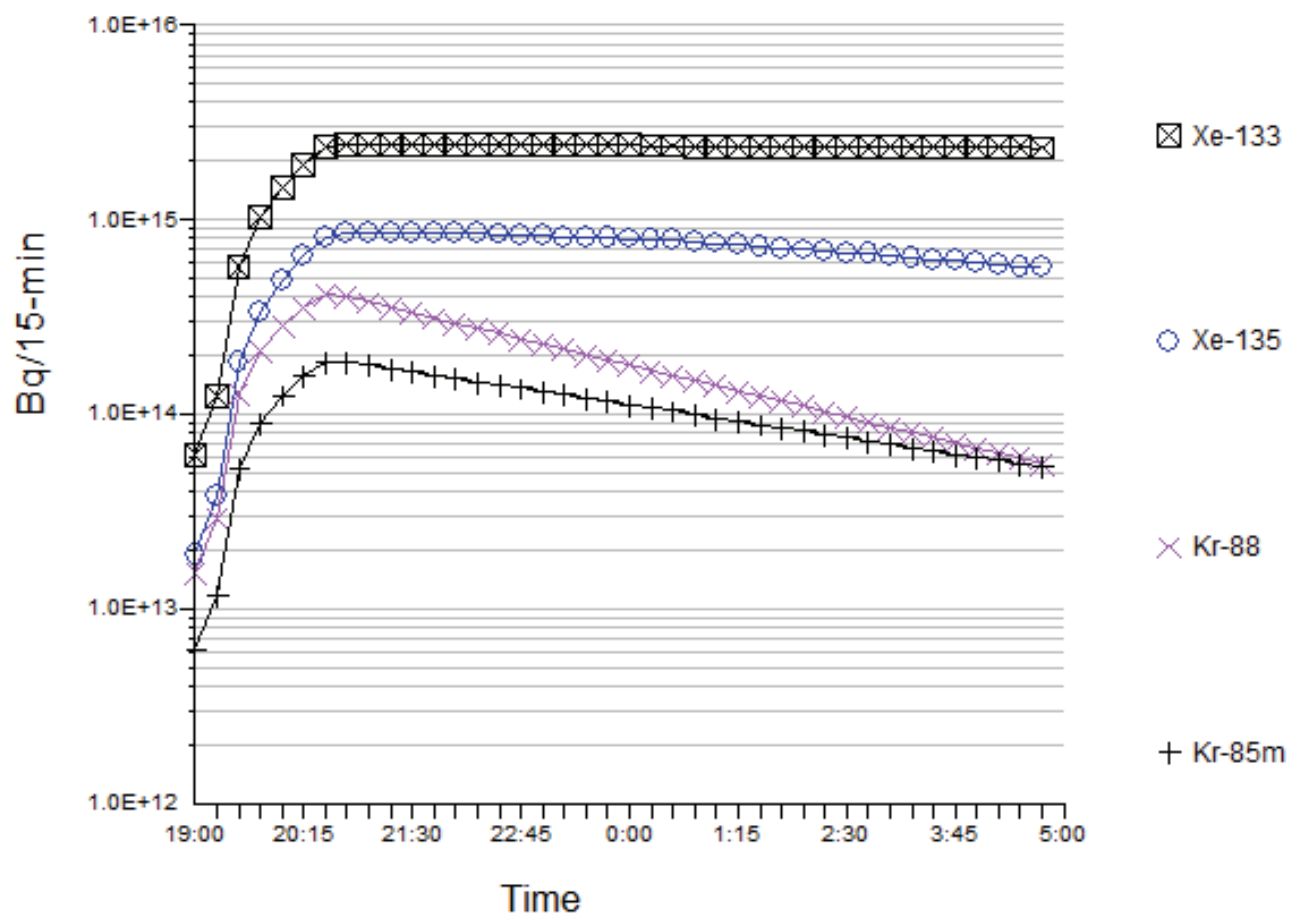

Fig. 5. Source Terms of ${ }^{133} \mathrm{Xe},{ }^{135} \mathrm{Xe},{ }^{88} \mathrm{Kr}$ and ${ }^{85 \mathrm{~m}} \mathrm{Kr}$ for LOCA

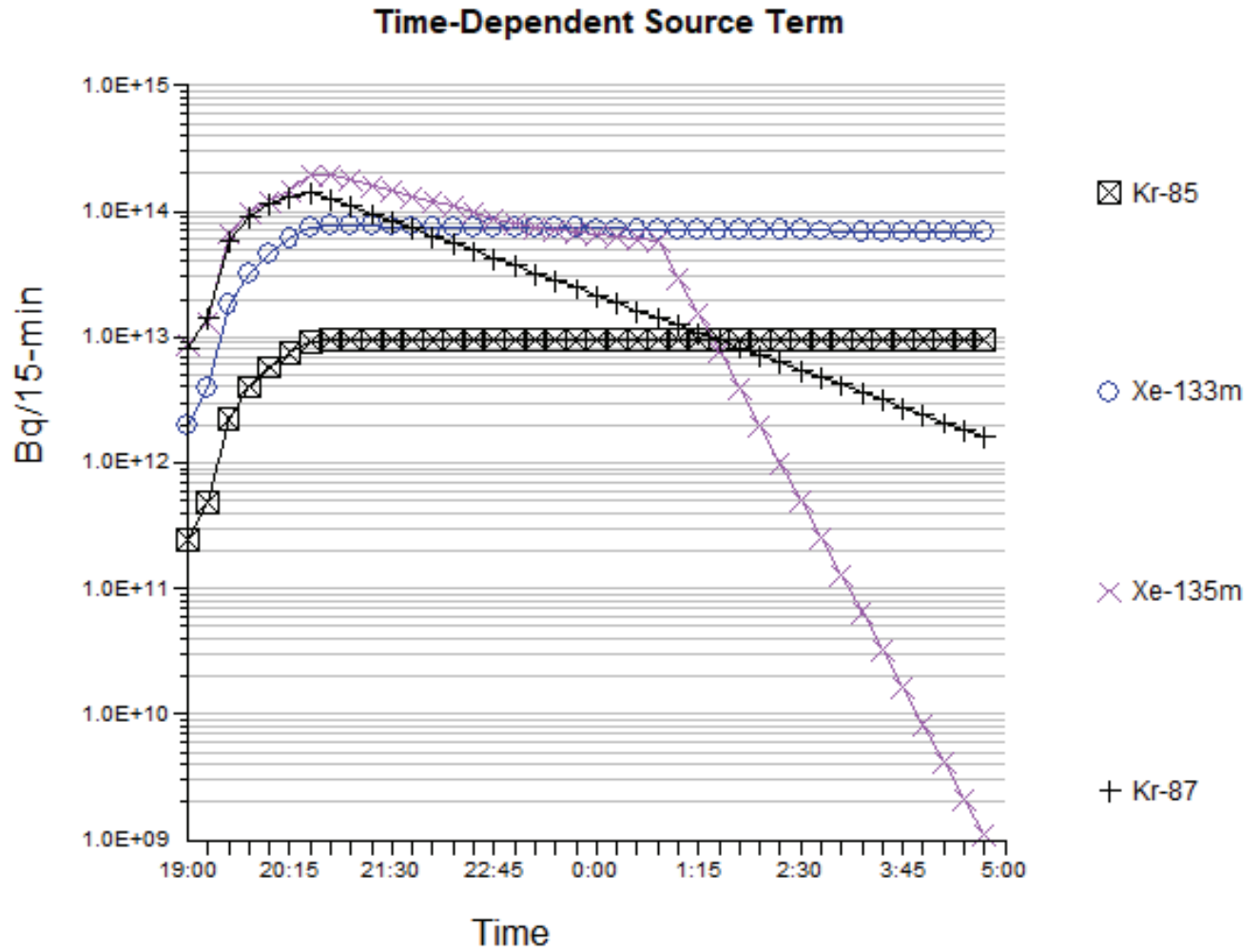

Fig. 6. Source Terms of ${ }^{85} \mathrm{Kr},{ }^{133 \mathrm{~m}} \mathrm{Xe},{ }^{135 \mathrm{~m}} \mathrm{Xe}$ and ${ }^{87} \mathrm{Kr}$ for LOCA 


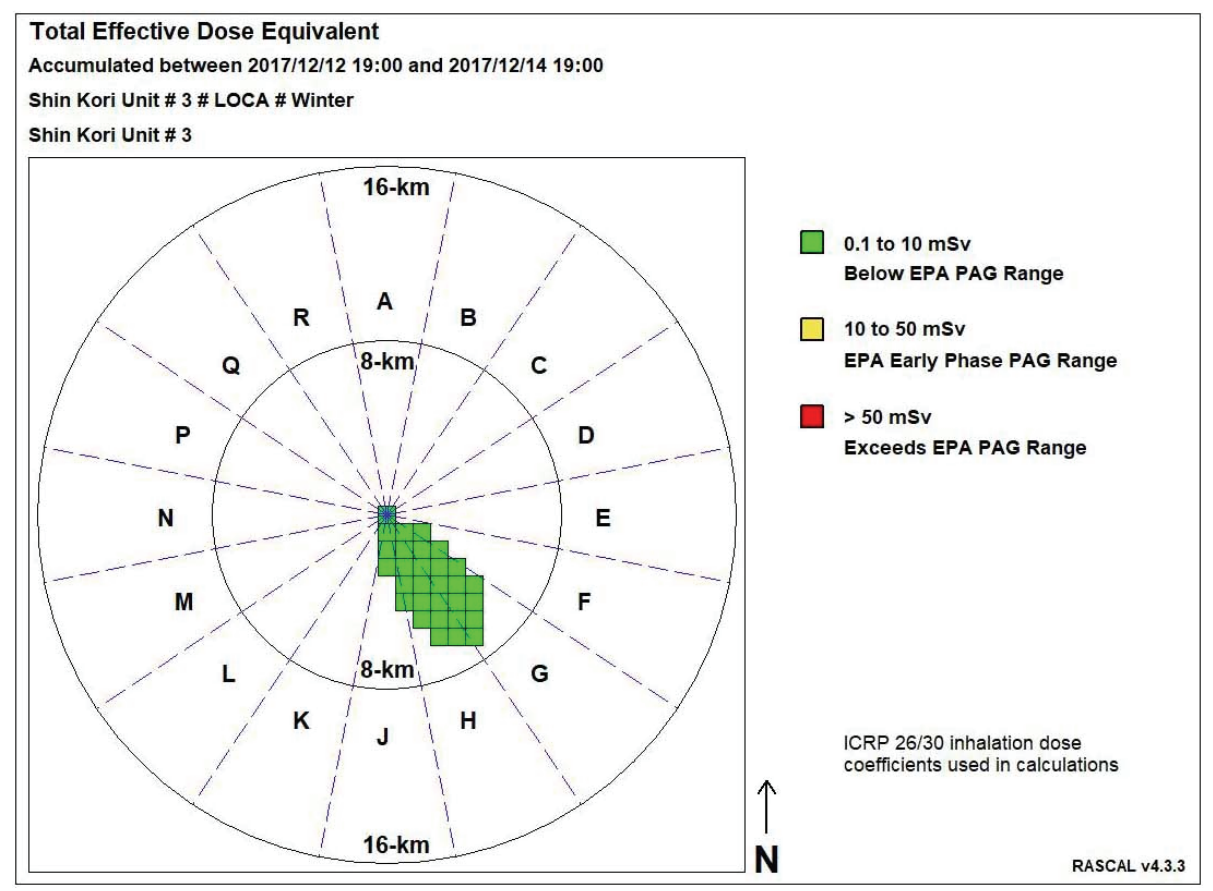

Fig. 7. Contour Plot of TEDE for LOCA

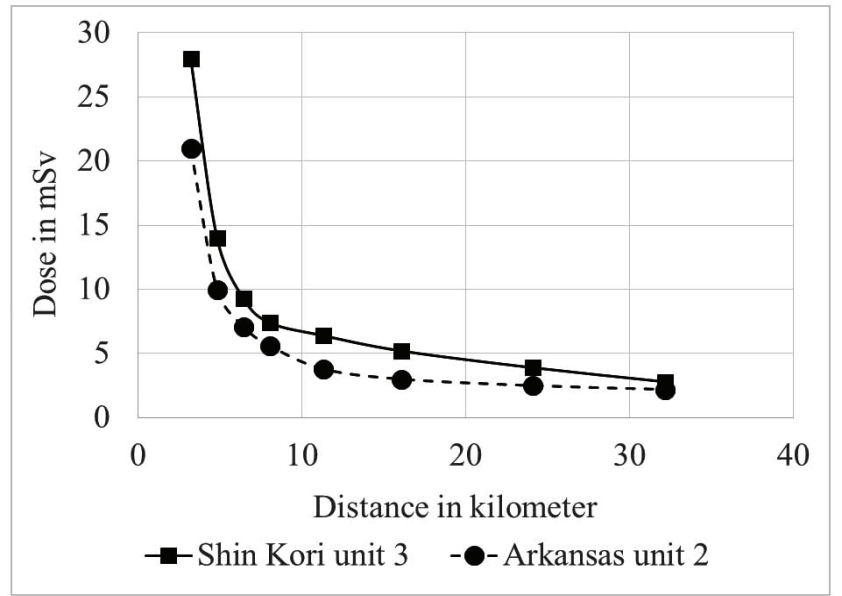

Fig. 8. Comparison Between Shin Kori Unit 3 and Arkansas Unit 2 for LTSBO

MWt and 3,645 MWt, respectively, and other reactor design parameters were similar with Shin Kori unit 3 (U.S. NRC, 2017b, 2017c).

\section{Conclusions}

The objective of this study was to analyze the off-site radiological consequences from hypothetical severe accidents of Shin Kori unit 3 along with the emergency protective levels in Korea. In order to investigate the effect of released radioactive materials to the public, TEDE and thyroid CDE were evaluated

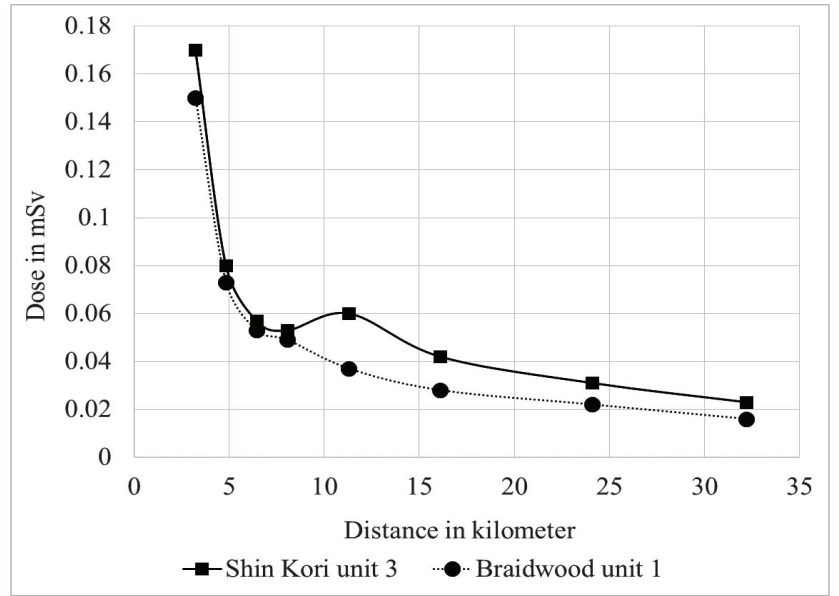

Fig. 9. Comparison Between Shin Kori Unit 3 and Braidwood Unit 1 for LOCA

using a regulatory software tool developed by U.S. NRC. Multiple simulations were performed considering reactor conditions and seasonal effects. In the event of LTSBO, TEDE and thyroid CDE were estimated to be $14 \mathrm{mSv}$ and $160 \mathrm{mSv}$, respectively, at about $5 \mathrm{~km}$ of $\mathrm{PAZ}$ in the evening time of winter season. Estimated values of TEDE and thyroid CDE in PAZ were higher than the Korean regulations on the indoor sheltering of $10 \mathrm{mSv}$ in 2 days and thyroid protection level of $100 \mathrm{mSv}$, and therefore it was found that more careful public protective measures of emergency management should be taken in the accident of LTSBO. 


\section{Acknowledgement}

This research was supported by the 2019 Research Fund of the KEPCO International Nuclear Graduate School (KINGS), the Republic of Korea.

\section{References}

Ahangari, R., Noori-Kalkhoran, O., and Sadeghi, N. (2017). Radiological dose assessment for the hypothetical severe accident of the Tehran Research Reactor and corresponding emergency response. Ann. Nucl. Energy, Elsevier, Vol. 99, pp. 272-278.

Athey, G.F., Rishel, J.P., Ramsdell, J.V., and Tomon, J.J. (2015). RASCAL 4.3: User's guide. U.S. Nuclear Regulatory Commission, Washington, D.C.

Korea Electric Power Corporation (KEPCO) and Korea Hydro \& Nuclear Power Co. (KHNP) (2014). APR1400 Design control document TIER 2.

Korea Meteorological Administration (KMA). (2019). Retrieved from https://data.kma.go.kr

Lee, J.H., Jeong, J.J., Shin, W.K., Song, E.Y., and Cho, C.W. (2016). The estimated evacuation time for the emergency planning zone of the Kori nuclear site, with a focus on the precautionary action zone. $J$. Radiat. Prot. Res., KARP, Vol. 41, No. 3, pp. 196-205.
Uddin, G.M.B. (2019). Nuclear emergency management using accident consequence analysis code. Master's thesis in preparation, KEPCO International Nuclear Graduate School, Ulsan, Korea.

U.S. Nuclear Regulatory Commission (U.S. NRC). (2012). State-of-the-art reactor consequence analyses (SOARCA) report. NUREG-1935. Washington, D.C.

U.S. Nuclear regulatory Commission (U.S. NRC). (2017a). RASCAL 4.3.3 Computer program. Washington, D.C.

U.S. Nuclear Regulatory Commission (U.S. NRC). (2017b). RASCAL 4 Tutorial, Rev 1.0, nuclear power plantPWR: Long-term station blackout (LTSBO). Washington, D.C.

U.S. Nuclear Regulatory Commission (U.S. NRC). (2017c). RASCAL 4 Tutorial, Rev 1.0, nuclear power plantPWR: Loss-of-coolant accident (LOCA). Washington, D.C.

Zhao, Y., Zhang, L., and Tong, J. (2015). Development of rapid atmospheric source term estimation system for AP1000 nuclear power plant. Prog. Nucl. Energy, Elsevier, Vol. 81, pp. 264-275.

\begin{tabular}{l|l} 
Received & May 20, 2019 \\
Revised & May 24, 2019 \\
Accepted & July 16, 2019
\end{tabular}

